Ana ȚĂRANU

Faculty of Letters, Babeş-Bolyai University

Cluj-Napoca, Romania

taranuanamaria@gmail.com

\title{
SIGNIFYING THE SELF: CULTURAL TRAUMA AND MECHANISMS OF \\ MEMORIALIZATION IN ZORA NEALE HURSTON'S \\ THEIR EYES WERE WATCHING GOD
}

\begin{abstract}
Recommended Citation: Țăranu, Ana. "Signifying the Self: Cultural Trauma and Mechanisms of Memorialization in Zora Neale Hurston's Their Eyes Were Watching God." Metacritic Journal for Comparative Studies and Theory 7.1 (2021): https://doi.org/10.24193/mjcst.2021.11.12
\end{abstract}

\begin{abstract}
Starting from Hirsch and Smith's concept of a feminist counterhistory and referencing the theoretical framework of cultural trauma, this paper undertakes a (re)reading of Zora Neale Hurston's Their Eyes Were Watching God as construction of gendered countermemory. Such an interpretation would enable a recognition of the political function of the novel as an identity matrix of African-American womanhood. Expanding upon the classical, post-Lacanian approach to trauma studies and its postcolonial reconfigurations, I use a poststructuralist framing of collective trauma, and the Saussurian concept of signification, to highlight the struggle for self-determination of an oppressed community as it is signified-upon by its oppressors through violently imposed discourse. I further question the complicity between conventional forms of narration and the hegemony of an external signifier, and I trace this patterned mechanism of aggression within the linguistic and diegetic fabric of the novel, in order to expose Hurston's literary methodology of collective memorialization and the way it challenges canonical representations of trauma.
\end{abstract}

Keywords: cultural memory, trauma studies, Zora Neale Hurston, countermemory, collective trauma, gendered violence

The opening paragraphs of Zora Neale Hurston's Their Eyes Were Watching God contain a richly lyrical description of a gendered construction of reality, demarcating the female ability of self-signifying through an active formulation of counter-memory. 
Through a subversion of conventional masculine imagery, the narrator subordinates the generative prospects of male reality to an unnamed higher power, and further reinforces the passivity of the male position by intrinsically linking it to a Sisyphean act of eternally impotent visuality: "Ships at a distance have every man's wish on board. For some they come in with the tide. For others they sail forever on the horizon, never out of sight, never landing until the Watcher turns his eyes away in resignation, his dreams mocked to death by Time" (Hurston 1). Initially, the internal temporality of the narrative is only marked by the circular, indeterminate pattern of the tide. The insertion of "Time," unexpectedly cruel and stripped of conventional abstraction, marks a fracture in the previously ahistorical nature of the scene, establishing the hegemony of an omnipotent History over "the life of men" (1).

It is against this pattern of inert waiting and resignation that the narrator constructs the model of female memorialization. Forgetting and remembering become performative negotiations of reality, and of the self: "women forget all those things they don't want to remember and remember everything they don't want to forget" (1). Thus, the female (re)making of the world is a selective act of interpretation in which the past is brought outside chronology and reconfigured. Reality cannot be judged against the hegemonic category of historical truth anymore: it is arrested within the oneiric, and therefore sheltered from the destructive quality of Time: "The dream is the truth" (1). Ultimately, it is by inhabiting this fecund reconfiguration of male ontology that women "act and do things accordingly" (1), narrating themselves into a self-determined existence. The subsequent insertion of the protagonist inscribes her within this female mechanism of interpretative reality-building, therefore revealing the formula of the narrative that is about to commence: a navigation of this woman's dreamscape, suspended outside the reach of conventional representation. The very sentence which introduces Janie violates the expectations of formulaic narration, as it implies a customary "at the beginning" which then refuses to fulfil, thus avoiding to locate the protagonist within a burdensome narrative time, and evading, by extension, her reification at the hands of narrative authority. Instead, the woman is the beginning. Rather than being confined to the narrative, she contains it and proceeds to assert full agency over the conditions of its unfolding.

It can be argued that these incipient paragraphs deliver a heuristic imperative by establishing "a model of reading, of understanding an oral or written text" (Wolff 29), and thus enabling the reader to actively and vividly perceive the novel in its 
qualitative progression, as a sensually immediate movement, or as "the lyric formulation of a personal vision" (29). By probing the lyrical mood of Hurston's prose and the reiterative nature of certain crucial scenes which end up attaining symbolic quality, Maria Tai Wolff revealingly argues that the novel constitutes itself as an assemblage of "successive scenes of self-recognition," which are coagulated as a voluminous revelation of the protagonist to herself and to the reader. Steeped in what Ralph Freedman deems "lyrical immediacy," the narration thus renounces the representational dictum of realist prose and its conventional forms of intradiegetic authority. Instead, the novel rather blatantly engages its reader in formulas of recognition and self-aware delineation of their own perceptive experience. In Wolff's words, the text prompts its reader to "formulate oneself" (33). Building on Wolff's assertion that the novel entails a model of active readership, and on its literary genealogy and inherent ideological impetus, I argue that, while still pertaining to the act of recognition as its central gesture, the novel stretches beyond selfhood and the reshuffling of individual memory, towards the domain of collective remembrance.

The reception history of the novel enables such a framing, since it was not regarded, upon its publication in 1937, as an exhibit of formal innovations. Instead, it was considered rather as socially retrograde, lacking sociological observation and political critique, particularly in comparison to the dominant literary forms pushed by social realism. In her blatant refusal of racial pathology, the author was said to have resorted to a complacent and perversely idealized account of African-American Southern womanhood, given that the story focuses on the protagonist's romantic life and refuses to explicitly engage in social or political critique. In the words of Richard Wright, the novel contained "no theme, no message, no thought," masterfully enabling a "minstrel technique" aimed to please and engage with white audiences. The rehabilitation of Zora Neale Hurston's legacy as both littérateur and cultural theorist, after the rediscovery of her work by Alice Walker in 1975 - in itself part of a wider effort to establish a genealogy of the literary voice of African-American womanhood enabled a critical reassessment of Their Eyes Were Watching God. Recent readings have emphasized its emancipatory drive, rethinking its plot in terms of the protagonist's progressive political self-assertion ${ }^{1}$.

\footnotetext{
${ }^{1}$ See Ryan Simmons, "'The Hierarchy Itself': Hurston's Their Eyes Were Watching God and the Sacrifice of Narrative Authority" (182), for an overview of recent criticism, followed by a rendition of Hurston's narrative dismantling of the hierarchical principle as such; See also Sigrid King, "Naming and Power in Zora Neale Hurston's Their Eyes Were Watching God" for an analysis of the relationship
} 
The present paper is inscribed within this critical stance. Starting from Hirsch and Smith's concept of a feminist counterhistory and referencing the theoretical framework of cultural trauma, the paper undertakes a (re)reading of Zora Neale Hurston's Their Eyes Were Watching God as a self-aware construction of gendered countermemory. Expanding upon the classical, post-Lacanian approach to trauma studies and its post-colonial reconfigurations, I subsequently use a structuralist framing of collective trauma, defined against the Saussurian concept of signification and highlighting the struggle for self-determination of an oppressed community as it is signified-upon by its oppressors through violently imposed discourse. I further question the complicity between conventional forms of narration and the hegemony of an external signifier, and I trace this patterned mechanism of aggression within the linguistic and diegetic fabric of the novel, in order to expose Hurston's literary methodology of collective memorialization and the way it challenges canonical representations of trauma.

Cultural memory is, in James Young's account, "received history" (Young 41); it entails "an act of telling and listening, performing and watching, [...] of 'twicebehaved behavior" (Hirsch and Smith 9). Its archives, unlike the ones of traditional history, "consist not only of the stories, images, or documents of the past, but also of the 'acts of transfer' without which we would have no access to them" (Hirsch and Smith 9). In other words, cultural memory entails dislocating any monologic understanding of the past as an intangible product of historical objectivity, and relocating it on the interpretative spectrum of the present and under the influence of intergenerational negotiation. As Deborah McDowell phrases it, "what we call the past is merely a function and production of a continuous present and its discourses" (McDowell 147). Cultural memory is therefore constituted as a product of collective mediation and can be articulated by means of varied technologies of memorialization: performative practices, representational media, and, most resonantly, literary narrative. Given that the recalling of a shared past "on the basis of common, and therefore often contested, norms, conventions, and practices" (Hirsch and Smith 5) is the fundamental act by which individuals or groups constitute their identity, to analyse

\footnotetext{
between language and self-assertion, and Sharon Davie, "Free Mules, Talking Buzzards, and Cracked Plates: The Politics of Dislocation in Their Eyes Were Watching God" for an analysis of the political charge exhibited by the narrative's disruptive formula.
} 
its relationship to hegemonic power structures is essential in the recovery of lost narratives and the comprehension of current identity forms.

This process is particularly relevant for communities whose historical narratives of oppression have undergone systemic forgetting, enacted either through their misrepresentation, or through exclusion from the framework of hegemonic cultural memory. On that account, recent feminist scholarship has proposed the construction of a female counterhistory, a theoretical attempt to "restore to hegemonic cultural memory the stories that have been forgotten or erased from the historical record" (Hirsch and Smith 11) by defamiliarizing and revising "traditional modes of knowing the past" and exposing "the psychological and political structures of forgetting or repression that have disempowered women or enabled them to veil their own painful past lives" (Hirsch and Smith 4). In this sense, Alice Walker's work to unearth and rehabilitate African-American female writers, which prompted her rediscovery of Zora Neale Hurston in 1975, is an eloquent example of such an effort, whose premises had been articulated by Walker in her 1972 essay, "In Search of Our Mother's Gardens.” The ethical imperative of such endeavours becomes specifically acute within communities that have undergone social oppression and systemic violence, to the extent that they have been constituted into both individual consciousness and collective memory as traumatic.

Conventional approaches in trauma theory, as prefigured by the seminal poststructuralist psychoanalytic literature of the late 1990s, theorize the traumatic experience by emphasizing its "repressive, repetitive and dissociative" (Balaev 5) character and inherent unrepresentability. ${ }^{2}$ The traumatic event is of such overwhelming and unassimilable nature that the self-absents itself from the direct experience of it. Its survival in the consciousness does not take the shape of a chronologically coherent, narratable story, but rather that of an eclipse or distortion of memory that resists conventional comprehension. Therefore, the trauma is not confined to the punctual experience of the unregistered initial event, but rather comprises the ulterior violation of the psyche, as it happens from within its apparent containment. The returns of the trauma do not enter the order of the narratable, instead manifesting themselves as "intrusive, belatedly experienced, and

\footnotetext{
2 Particularly Cathy Caruth's Unclaimed Experience: Trauma, Narrative, and History and Kali Tal's Worlds of Hurt: Reading the Literatures of Trauma, both published in 1996, and fundamental in shaping the course of initial literary trauma theory, particularly through their insistence on the inherent unrepresentability of trauma.
} 
achronological memorial shards" (Forter 70), the truth value of which can be preserved only insofar as "they are not sublated into conventional linear narration" (Forter 70). Consequently, the Lacanian approach, particularly Cathy Caruth's "deconstructive criticism" (Balaev 1), constitutes itself around "linguistic indeterminacy, ambiguous referentiality, and aporia” (Balaev 1). Language ultimately fails to locate the truth of the traumatic past, which remains confined within the elusive rhetorical territory of the unspeakable. 3 The portrayal of trauma as a prelinguistic event and of narrative as an inadequate instrument in recovering the trauma's remote historical truth have undeniably influenced canonical tendencies in its literary portrayal. Works that are underlined by such a paradigm restrict themselves to conventional representations of individual psychic disorientation and deformation of memory. In their ethical pledge of faithfulness to the original experience, these works generally contain "an exile from chronological sequence and into the compulsive repetition of past injuries" and a writing style that must "mime and transmit to readers a break in linear, conventionally narrative representation" (Forter 71).

Their Eyes Were Watching God also includes depictions of individually experienced trauma, albeit enclosed within a narrative formula that is restrained in its engagement with the previously described representative conventions. An example is Nanny's account of being brutally aggressed by her white mistress shortly after giving birth to Janie's mother. Narrated in first person, the recounted scene is of evident traumatic character, as signalled by the character's noted inability to react to the disruptive intensity of the violent experience: "Ah had too many feelin's tuh tell which one to follow so Ah didn't cry and Ah didn't do nothing else" (Hurston 24). Following an analogous pattern, Janie's recurrent dislocations of self can be similarly linked to her prolonged exposure to oppressive relationships culminating with her being forcefully silenced by Joe Starks for most of their marriage. Enacting what can be psychoanalytically regarded as a defence mechanism, she absents herself from directly experiencing the otherwise unbearable reality of her life: "one day she sat and watched

\footnotetext{
3 A distinction ought to be made between the unspeakable as a rhetorical trope recurrently used in the critical literature of trauma theory and the unspeakable as a psychological phenomenon entailing the inability or refusal of the survivor or the witness to give an account of the traumatic experience, as pointed out by Barry Stampfl in "Parsing the Unspeakable in the Context of Trauma." Framing the unspeakable as singular and a "predetermined endpoint of the traumatic experience," instead of understanding it as "merely a phase in the process of traumatization," enables deep ethical consequences in its often-misguided validation of moral authority. In other words, an employment of the rhetoric mechanism of the unspeakable allows a turning away from the social causes of the trauma.
} 
the shadow of herself going about tending the store and prostrating itself before Jody, while all the time she herself sat under a shady tree" (103). The metaphorical metabolization of this psychological phenomenon is charted spatially, for Jaine consciously constructs a mental refuge where she can preserve her youthful self and shelter it from the dehumanizing effects of her traumatizing environment. Significantly, this compensatory space is modelled on the idyllic garden setting which dominates the imagery of her early adolescence and holds the first recognitions of her sexuality. It is only following the death of her oppressive husband that she can recover her younger self, undo the premature aging enforced on her and fully assert agency over her previously stifled sexual expression: "Years ago, she had told her girl self to wait for her in the looking glass. It had been a long time since she had remembered. The young girl was gone, but a handsome woman had taken her place. She tore off the kerchief from her head and let down her plentiful hair. The weight, the length, the glory was there" (117).

Whereas exhibiting a conventional narration of the individually traumatic, these scenes also manage to imply a wider, collective background, insofar as they expose the existence of a broader mechanism of traumatization, which perverts the characters' interpersonal dynamics. This is the case if we think of both the racial violence scene, which Nanny is a victim of, or of the harmful model of hegemonic authority that Joe Starks aggressively tries to mimic. To identify the narration's patterns within the novel and to spell them out in terms of their traumatic character, one has to acknowledge first that the previously referenced psychoanalytic model is a deficient tool in mapping out collective experience, for it is inherently tied to a notion of trauma as individually experienced and exclusively linked to a punctual event. The conceptual salience of trauma to the study of slavery and its ulterior cultural consequences is evident, insofar as race relations are "always and everywhere relations of domination" (Forter 70), a constitutive feature of which is the "potential for traumatization" (70) of the individual psyche. However, the collective consequences of systemic oppression are poorly accommodated within the symptomatic range of the classical model, particularly given that it does not concern itself with the issues of transgenerational cultural memory and the negotiation of collective identity.

Therefore, the engagement of the complementary theoretical framework of collective trauma becomes particularly significant. Defining collective trauma, Kai Erikson asserts that it does not merely refer to a community whose members 
individually experience trauma, but rather to one that has its very nature transfigured as an effect of the traumatic event. In this sense, "traumatic experiences work their way so thoroughly into the grain of the affected community that they come to supply its prevailing mood and temper, dominate its imagery and its sense of self [and] govern the way its members relate to one another" (Erikson 190). In his monograph on the formation of African-American identity, Ron Eyerman regards the collective trauma of slavery not as an "institution or even experience, but as collective memory, a form of remembrance that grounded the identity-formation of a people" (Eyerman 1). Treated as a cultural process, and in opposition to psychological trauma, "which involves a wound and the experience of great emotional anguish by an individual," cultural trauma therefore refers to a "dramatic loss of identity and meaning, a tear in the social fabric, affecting a group of people that has achieved some degree of cohesion" (2). Slavery retains its traumatic character in a retroactive and transgenerational manner and a direct experience of its atrocities by the members of the community is not a prerogative of it being established as traumatic. It is only by means of public mediation and representation that the memory of the trauma is delineated, understood and accepted. Thus, "trauma always engages a "meaning struggle" (3) in which the collective experience of massive disruption shifts into a crisis of meaning and identity.

Approaching the dynamics of the "meaning struggle" from a structuralist perspective, historian of religions Charles Long theorizes the same phenomenon by operating with the Saussurian concept of signification, which he reformulates with reference to the case of the African-American community as a "subordinate relationship of power expressed through custom and legal structures” (Long 1):

As Saussure put it, "The bond between the signifier and the signified is arbitrary." The signifiers of my community knew this and thus through tone of voice, and the injection of new words and phrases, attempted to form new and different relationships within a discourse that was already taking place. [...] On the one hand, the fact that signification represented an arbitrary relationship between the signifier and the signified meant that the relationship could be changed, while on the other hand, the very fact that the relationship was arbitrary was the source of its terror (2).

On a collective level, the very position of being signified upon exhibits a traumatic character. The struggle for self-determination within hegemonic discourse entails the 
community undercutting "this legitimated signification with a signification upon this legitimated signifying" (2), therefore constraining its social mediation and cultural representation to the mechanisms of the hegemonic discourse it struggles against. Hence, to address the traumatic consequences of being signified upon requires a collective negotiation of the community discourse, by means of which a selfdetermined re-signifying is attempted. Literature preeminently accommodates such reassessment. Particularly within the domain of the narrative, inherently inclined to enable recovery from the disruption of the traumatic experience, literary forms perform as powerful meeting points of the intimate and the political. In this sense, they lay out genuine methodologies of memorialization and assertion of self, particularly when embedded in the cultural consciousness of a community the past oppression of which necessitates contemporary mediation. In its very format, literature accommodates testimony. Then, in focusing on the story of the individual, it illustrates the social formation in its heterogeneity, and can serve as "a challenge and a countermemory to official hegemonic history" (Hirsch and Smith 3).

I argue that it is in full awareness of this fact that Zora Neale Hurston's prose should be regarded, functioning as a building site for what Henry Louis Gates Jr. terms a formally innovative "communal narration." Among the patterns of violence that permeate Their Eyes Were Watching God, the oppressive signifying upon is prevalent and repeatedly addressed. In cantering Janie's tumultuous fulfilment as an autonomous, self-signified voice, the narrative showcases a number of relationships which transmute hurtful dynamics of racial domination into the domain of the personal and the intimate, metonymically perpetuating the community's cultural trauma. Reading Their Eyes Were Watching God as a challenge to the representational canon of traumatic racial relationships enables a recognition of the methodology of memorialization that Zora Neale Hurston puts forward, the intradiegetic functioning of which exposes the dialectic relationship between psychic and social trauma, particularly in terms of their reciprocal causation and sustenance.

The narrative is comprised of two distinct levels: the first one, to which the reader is introduced initially, follows Janie's unexpected return to Eatonville and her meaningful reunion with an old friend, Pheoby. It is towards her that she performs a potent transfer of memory by sharing a complete account of her life. Within this oral recollection a second plane is set up, which contains the main narrative nuclei of Janie's chronologically structured recollection: a number of childhood episodes, being 
forcibly married off by her grandmother, escaping this first unhappy marriage into an equally stifling one, and a third, emotionally fulfilling relationship, which ends tragically with the death of her spouse. Even though the presence of a narrator discernably permeates the text, its authority is receding and volatile, meaningfully maintaining the protagonist's agency over her self-determined act of telling, in line with the auctorial stance set up within the book's opening paragraphs.

The prose conducts itself as a self-aware performance of language, underlined by the intuition of the complicity between conventional forms of narration and the hegemony of the external signifier. To give genuine voice to African-American womanhood from within the representational canon, the author must attempt a subversion of the canonical order. This process is carried out linguistically and symbolically within the very fabric of her writing, and ultimately shapes her innovative model of literary narrative. 4 Her anthropologically informed understanding of the collective past as folklore to be preserved and mined for meaning is displayed in her aesthetic commitments as a writer, primarily in her heightened awareness of the rich figurative potential of African-American vernacular. This concern for language is characteristic of her entire oeuvre, eventually assembling a theory of language and behavior, as Henry Louis Gates, Jr. pointedly notes: "Invariably, Hurston's writing depends for its strength on the text, not the context" (Gates Jr. 293). The persistently dissociative character of the narrative voice eloquently mirrors the traumatic struggle for a unitary signifying of self that the protagonist, and, isomorphically, the community, experiences, as Henry Louis Gates Jr. notes:

Hurston uses the two voices in her text to celebrate the psychological fragmentation both of modernity and of the black American. [...] hers is a rhetoric of division, rather than a fiction of psychological unity. Zora Neale Hurston, the 'real' Zora Neale Hurston that we long to locate in this text, dwells in the silence that separates these two voices: she is both, and neither; bilingual, and mute (296).

\footnotetext{
4 The subversive nature of Zora Neale Hurston's literary language has been acknowledged and theoretically approached repeatedly; notably, Sharon Davie argues that "central to the pleasure and influence of this novel are those moments in the text that pull the cultural rug out from under the readers' feet, disturbing their complacent belief in the 'mastery', as Julia Kristeva calls it , of a rational and hierarchical ordering of the world" (Davie 446) and articulating the prose beyond the constraints of ideological discourse. An alternative perspective is offered by Henry Louis Gates, Jr. in The Signifying Monkey. As Davie points out, he argues that such literary discourse, which evades normative cultural modes of perception, "is linked to an Afrocentric worldview epitomized by Esu, the African trickster god who mocks binary either-or categorization" (447).
} 
Language is conceived as profoundly intimate and culturally specific, an active and conscious performance of selfhood that the author conducts with remarkable artistry. Its use politically charges the text, for it is through and within language that power structures are exposed and the struggle for collective meaning commences, as the incipient scene of Janie's return to Eatonville shows in its description of the gathered community:

It was the time for sitting on porches beside the road. It was the time to hear things and talk. These sitters had been tongueless, earless, eyeless conveniences all day long. Mules and other brutes had occupied their skins. But now, the sun and the bossman were gone, so the skins felt powerful and human. They became lords of sounds and lesser things. They passed nations through their mouths. They sat in judgement (Hurston 2).

The porch congregation apparently constructs its power dynamic outside the relationships of conventional oppression that account for the quotidian dehumanization of its members. Language, as it is engaged in various acts of speech, gains its ritualistic character by providing the only attainable route towards emancipation and creative relocation of the self through narrative projection: "They became lords ... of lesser things." (Hurston 2). However, the community's internal structure is shown to mimic hegemonic morphologies of power and, through them, a violent act of unknowledgeable signification upon the newly returned Janie. Speech acts do not retain their previously established regenerative nature, and language is reassessed as a primary instrument of violence and injury in a metaphorical rendition of the terminology of oppression: "It was mass cruelty. ... Words walking without masters" (Hurston 2).

The seamless movement of the narrative voice between first and third person warrants the establishment of Janie as an autonomous narrative agent of her own story and sheds particular significance on the biographical elements that she chooses to disclose. In the apparent absence of an oppressively omniscient narrator, the progression of her story does not pertain to the logic of conventional narrative, but rather to an internal logic of working-through the traumatic past, unconsciously charting disruptive events as she seeks to understand them. Aptly relying on 
metaphorical forms of coherence, Janie visualizes her life as "a great tree in leaf," the roots of which she struggles to locate: "Ah know exactly what Ah got to tell yuh, but it's hard to know where to start at." (Hurston 11) The recurrent image of the rootless tree is later linked to collective African-American suffering through Nanny's assertion that "[u]s colored folks is branches without roots and that makes things come round in queer ways" (Hurston 21). The uprootedness reads like an unreconciled absence of self-asserted meaning that affects the community in its most elementary relationships. In light of her previously expressed biographical disorientation, the fact that Janie begins her story with an instantiation of absence reveals the depth of its effects: "Ah ain't never seen mah papa. [...] Mah mama neither." (Hurston 11).

Her central familial figure is her grandmother and the account of their relationship best exposes the network of transgenerational trauma and the ways in which it malforms intimacy. Given that the grandmother works as a caretaker for the children of a white family, alongside which she raises Janie, she is never called anything "but Nanny, 'cause dat's what everybody on de place called her" (Hurston 11). Systemic oppression infiltrates their familial relationship even on the most elementary level of naming, in that Janie never verbally appropriates the affective particularity of their bond, instead adopting the lexicon of the white children among whom she grows up. The verbal unawareness of her intrinsic link to her grandmother mirrors her early unawareness of race and, most importantly, her inability to register race as a constitutive factor of her identity: "Ah was wid dem white chillun so much till Ah didn't know Ah wuzn't white till Ah was round six years old" (Hurston 12). Among the most disruptive of her childhood memories is the enforced realization of her race. The dynamics of the scene perfectly illustrate, on the scale of the infantile consciousness, the struggle for self-signifying and the oppressive nature of being signified upon. A photo is taken of the children of the family and, upon looking at it, she is unable to identify herself: "So when we looked at de picture and everybody got pointed out there wasn't nobody left except a real dark little girl with long hair standing by Eleanor. Dat's where Ah wuz s'posed to be, but Ah couldn't recognize dat dark chile as me. So Ah ast, 'where is me? Ah don't see me" (Hurston 12). The constitutive openness of her childhood identity is also marked in denomination; she is called "Alphabet 'cause so many people had done named me different names." (Hurston 12). 5 Subsequently, the

5 The incident is of particular cultural relevance because it highlights the wider relationship between naming and power structures within African-American culture. Michael Cooke illustrates this concern 
reaction of the gathered adults to Janie's recognition of her race further invalidates her struggle to comprehend herself: "Everybody laughed, even Mr. Washburn. Miss Nellie [...] pointed to de dark one and said, 'Dat's you, Alphabet, don't you know yo' ownself?" (Hurston 12). Although she gives a comprehensive account of childhood episodes, Janie is not the one to directly disclose the circumstances of her birth. Nanny recounts the violent rape of her daughter by a school teacher, a horrifying act of gendered violence leading to Janie's birth. It is also in Nanny's voice that the story of her own rape by a white master is told, framed by the disturbing cruelty that the mistress manifests against her and her daughter. In both cases, it is her close witnessing of the events that drives her consciously conducted acts of telling.

The narrative is henceforth molded into a mining of transgenerational suffering. It gives voice and agency to the survivor of the traumatizing violence, or to the most direct witness of it, therefore pioneering a mode of direct knowledge that underlines the entire narrative, and functions as the ethically coherent alternative to oppressive signification. This theory of knowledge and transmission is enunciated by Nanny (“we don't know nothin' but what we see”) and underlines the entirety of Janie's construction of self, ultimately constituting the empowering conclusion of her arc. Of profound emancipatory function, it hints at the possibility of social healing by escaping a hegemonically enforced identity through a commitment to the acquisition of direct and self-determined knowledge. This quest towards an intimate understanding of the world is connoted as an existential duty and suggested as a pattern of collective behavior: "It's uh known fact, Phoeby. You got tuh go there tuh know there. Yo' papa and yo' mama and nobody else can't tell yuh and show yuh. Two things everybody's got tuh do fuh theyselves. They got tuh go tuh God, and they got tuh find out about livin' fuh theyselves" (Hurston 258).

It is within this methodology of recuperative knowledge, of the past as a fluid narrative and the future as open to a complete exercise of agency, that the counterhistorical imperative of Their Eyes Were Watching God can be justifiably looked for. Approaching Zora Neale Hurston's writing from within the theoretical framework of cultural trauma constitutes a relevant opportunity for its recovery as

with naming in relation to identity construction: "[t]o have a name is to have a means of locating, extending, and preserving oneself in the human community, so as to be able to answer the question 'who?' with reference to ancestry, current status and particular bearing, with reference to the full panoply of time." (Cooke 171). 
conscious act of giving meaning and self-signified identity to African-American womanhood. In the words of Henry Gates, Jr., "[i]n a tradition in which male authors have ardently denied black literary ancestry, [...] Zora and her daughters are a tradition-within-a-tradition, a black woman's voice” (Gates Jr. 292).

\section{References:}

Balaev, Michelle. Contemporary Approaches in Literary Trauma Theory. Macmillan, 2014 .

Caruth, Cathy. Trauma: Explorations in Memory. Johns Hopkins University Press, 1995.

Clarke, Deborah. "'The Porch Couldn't Talk for Looking': Voice and Vision in Their Eyes Were Watching God." African American Review 35.4 (2001): 599-613.

Degloma, Thomas. "Expanding Trauma through Space and Time: Mapping the Rhetorical Strategies of Trauma Carrier Groups.” Social Psychology Quarterly 72.2 (2009): 105-22.

Davie, Sharon. "Free Mules, Talking Buzzards, and Cracked Plates: The Politics of Dislocation in Their Eyes Were Watching God." PMLA 108.3 (1993): 446-59.

Erikson, Kai. "Notes on Trauma and Community." Trauma: Explorations in Memory. Ed. Cathy Caruth. Johns Hopkins University Press, 1995: 183-99.

Eyerman, Ron. Cultural Trauma: Slavery and the Formation of African American Identity. Cambridge University Press, 2001.

Forter, Greg. "Colonial Trauma, Utopian Carnality, Modernist Form: Toni Morrison's Beloved and Arundhati Roy's The God of Small Things." Contemporary Approaches in Literary Trauma Theory. Ed. Michelle Balaev, 2014: 70-105.

---, Greg. "Freud, Faulkner, Caruth: Trauma and the Politics of Literary Form." Narrative 15.3 (2007): 259-85.

Freed, Joanne Lipson. "Gendered Narratives of Trauma and Revision in Gayl Jones's 'Corregidora."' African American Review 44.3 (2011): 409-20.

Gates, Henry Louis, Jr. Afterword. Zora Neale Hurston: "A Negro Way of Saying." Mules and Men, by Zora Neale Hurston, ebook, Harper Collins, 2008: 287-99.

---, Henry Louis, Jr. The Signifying Monkey: A Theory of African-American Literary Criticism. Oxford University Press, 1988. 
Harvey, Marcus. “'Hard Skies’ and Bottomless Questions: Zora Neale Hurston's 'Their Eyes Were Watching God' and Epistemological 'Opacity' in Black Religious Experience.” Journal of Africana Religions 4.2 (2016): 186-214.

Hirsch, Marianne, and Valerie Smith. "Feminism and Cultural Memory: An Introduction.” Signs 28.1 (2002): 1-19.

Hurston, Zora Neale. Their Eyes Were Watching God. Virago, 2018.

King, Sigrid. "Naming and Power in Zora Neale Hurston's Their Eyes Were Watching God.” Black American Literature Forum 24.4 (1990): 683-96.

Long, Charles H. Significations: Signs, Symbols, and Images in the Interpretation of Religion. The Davies Group Publishers, 1999.

McDowell, Deborah E. "Negotiating between Tense: Witnessing Slavery after Freedom - Dessa Rose." Slavery and the Literary Imagination. Ed. Deborah E. McDowell and Arnold Rampersad. Johns Hopkins University Press, 1989: 14463.

Simmons, Ryan. “The Hierarchy Itself': Hurston's 'Their Eyes Were Watching God' and the Sacrifice of Narrative Authority." African American Review 36.2 (2002): 181-93.

Stepto, Robert B. From Behind the Veil: A Study of African-American Narrative. University of Illinois Press, 1991.

Walker, Alice. I Love Myself When I Am Laughing ... And Then Again When I Am Looking Mean and Impressive: A Zora Neale Hurston Reader. Feminist P, 1979.

Wolff, Maria Tai. "Listening and Living: Reading and Experience in 'Their Eyes Were Watching God'." Black American Literature Forum 16.1 (1982): 29-33.

Young, James E. “Toward a Received History of the Holocaust." History and Theory 36.4 (1997): 21-43. 